\title{
Manejo convencional de Spodoptera exigua en cultivos del municipio de Los Reyes de Juárez, Puebla*
}

\section{Conventional management of Spodoptera exigua in crops of the municipality of Los Reyes de Juárez, Puebla}

\author{
Javiera Estefany Barrientos-Gutiérrez ${ }^{1}$, Arturo Huerta-de la Peña ${ }^{1 \S}$, José Sergio Escobedo-Garrido y Jesús Francisco López- \\ Olguín ${ }^{2}$ \\ ${ }^{1}$ Colegio de Postgraduados-Campus Puebla. Carretera Federal México-Puebla km 125.5, Santiago Momoxpan, Municipio de San Pedro Cholula, Puebla. C. P. 72760 \\ México. ${ }^{2}$ Centro de Agroecología- Instituto de Ciencias, Benemérita Universidad Autónoma de Puebla. Avenida 14 Sur 6301, Colonia San Manuel, Puebla, Puebla, C. P. \\ 72570. (biosfera50yahoo.com; seresco@colpos.mx; olguin33@hotmail.com).`Autor para correspondencia: ahuertapena@yahoo.com.
}

\section{Resumen}

Spodoptera exigua es un insecto plaga de importancia agrícola mundial que afecta una gran variedad de cultivos, entre los que destacan ornamentales, granos básicos y hortalizas. El método de control más utilizado son los insecticidas químicos de síntesis; sin embargo, se han reportado cambios en la susceptibilidad del insecto a diversos insecticidas. Esta adaptación ha venido en aumento, existiendoreportes de un gran número de insecticidas para los cuales $S$. exigua ha desarrollado resistencia. En el municipio de Los Reyes de Juárez, Puebla se obtuvo información del manejo de este insecto y de cultivos afectados, mediante un muestreo simple aleatorio con varianza máxima, obteniendo un tamaño de muestra: $\mathrm{n}=160$ productores de un total de 1 300 registrados en el censo agrícola 2007. La aplicación de las encuestas semiestructuradas se realizó de Agosto de 2011 a enero de 2012. Los resultados indican que los cultivos más afectados por S. exigua fueron: acelga, brócoli y col. Los insecticidas convencionales más utilizados en el control de este insecto fueron: Clorpirifos-etil+Permetrina (22.7\%) y Carbofurán (21.8\%). La asesoría sobre el uso de insecticidas para el control de $S$. exigua, ésta es proporcionada por los vendedores de las casas comerciales de agroquímicos (33.1\%) o bien no reciben asesoría (49\%). Más de la mitad

\section{Abstract}

Spodoptera exigua is an agriculturally important insect pest worldwide that affects a variety of crops, among which are ornamental, grains and vegetables. The control methods used are synthetic chemical insecticides; however, there have been reports regarding changes in susceptibility to various insecticides. This adaptation has been increasing, and there are reports of a large number of insecticides to which $S$. exigua has developed resistance. In the municipality of Los Reyes de Juárez, Puebla management information was obtained of this insect and crops affected by simple random sampling with maximum variance, obtaining a sample size $\mathrm{n}=160$ producing a total of 1300 registered 2007 agricultural census. The application of semi-structured survey was conducted in August, 2011 to January, 2012. The results indicated that, the most affected crops by $S$. exigua were: spinach, broccoliand cabbage. The conventional insecticides used in the control of this insect were: Chlorpyrifos-ethyl+ Permethrin (22.7\%) and Carbofuran (21.8\%). The advice on the use of insecticides for the control of S. exigua is provided by the vendors of commercial houses of agrochemicals $(33.1 \%)$ or did not receive any help at all (49\%). More than half of the farmers (59\%) commented to conduct themselves applying insecticides, without any advice. Finally $18.7 \%$

\footnotetext{
* Recibido: enero de 2013 
de los agricultores (59\%) comentaron realizar ellos mismos la aplicación de los insecticidas, sin asesoría. Finalmente $18.7 \%$ de los productores mencionó haber sufrido alguna intoxicación como consecuencia de su exposición a los insecticidas utilizados en el manejo del gusano soldado.

Palabras clave: S. exigua, hortalizas, insecticidas, gusano soldado, plagas.

\section{Introducción}

Las plagas constituyen uno de los problemas a los cuales debe enfrentarse los agricultores, particularmente los insectos fitófagos son difíciles de combatir debido a su gran capacidad de adaptación. El gusano soldado (Spodoptera exigua), también conocido como rosquilla verde, trozador de la remolacha, gardama o gusano de la remolacha, es un insecto originario del Sureste Asiático que afecta a una gran cantidad de cultivos a nivel mundial. Las especies susceptibles a la presencia del insecto pertenecen a varias familias botánicas, pudiendo hallarse en una gran variedad de especies (Capinera, 2005).

Las zonas de distribución mundial actual de $S$. exigua comprenden el Norte y Sur de África, Oriente medio, Península Ibérica, Francia, Italia, Mar Negro, Balcanes, Inglaterra y Alemania (Pérez et al., 2003); además de Norteamérica y Latinoamérica. En México debido a sus hábitos polífagos $S$. exigua presenta una distribución amplia, así mismo los cultivos que se ven afectados por el insecto son diversos. Para el caso de México, S. exigua se considera una plaga de importancia económica que se presenta de manera cíclica afectando cultivos básicos (SAGARPA, 2002). En el estado de Puebla este insecto es considerado como una plaga importante del amaranto (Aragón y López-Olguín, 2001); asimismo, por observación directa se encontró en cultivos de los municipios de Acatzingo y Los Reyes de Juárez.

Existen diferentes métodos de control de S. exigua, siendo el uso de insecticidas de síntesis (tipo químico-sintético) contra los estados larvales de $S$. exigua, el método principal (Greenderg et al., 2005); sin embargo, el uso indiscriminado de éstos insecticidas ha provocado el desarrollo de resistencia de las poblaciones de $S$. exigua frente a un gran número de los compuestos utilizados. Actualmente se reporta resistencia, en diversos grados, a varias grupos de insecticidas como son los organoclorados, organofosforados, carbamatos y of farmers reported having experienced some intoxication as a result of their exposure to the insecticides used in the management of armyworm.

Key words: S. exigua, vegetables, insecticides, armyworm, pests.

\section{Introduction}

Pests are one of the problems which farmers must face; particularly phytophagous insects are difficult to control due to its adaptability. The beet armyworm (Spodoptera exigua), also known as green donut is an insect native to Southeast Asia that affects a lot of crops worldwide. Species susceptible to the insect belong to different botanical families, found in a variety of species (Capinera, 2005).

The current global distribution areas of S. exigua comprise the North and Southern Africa, the Middle East, the Iberian Peninsula, France, Italy, Black Sea, Balkans, England and Germany(Pérez et al., 2003), in addition to NorthAmerica and LatinAmerica. InMexicodue toits polyphagoushabits S. exigua has a wide distribution also the crops thatare affected by the bug are diverse. In the case of Mexico, S. exigua is considered a pest of economic importance that occurs in cycles affecting staple crops (SAGARPA, 2002). In the state of Puebla this insect is considered a major pest of amaranth (Aragón and LópezOlguín, 2001), also by directobservation was found in cultures of the municipalities of Acatzingo and Los Reyes de Juárez.

There are different control methods S. exigua, with the use of synthetic insecticides (chemical-synthetic type) against the larval stages of S. exigua, the main method (Greenderg et al., 2005), however, the indiscriminate use of these insecticides has led to the development of resistance in populations of S. exigua againsta large number of compounds used. Currently reported resistance in varying degrees, to several groups of insecticides such as organochlorines, organophosphates, carbamates and pyrethroids (Gore and Adamczyk, 2004; Ahmad and Arif, 2010), also a new and Spinosad insecticides (Wang etal.2006).

This research was conducted with farmers in the municipality ofthe Kings of Juárez,Puebla, who provided information on the crops that are affected by S. exigua, widely used insecticides for control of this insect, the security practices employed and people who perform the activity insecticide application, and received counseling service and poisonings among producers. 
piretroides (Gore y Adamczyk, 2004; Ahmad y Arif, 2010); asimismo, a insecticidas nuevos como Spinosad (Wang et al., 2006).

La presente investigación se llevó a cabo con los agricultores del municipio de los Reyes de Juárez, Puebla, quienes proporcionaron información sobre los cultivos que se ven afectados por S. exigua, los insecticidas más utilizados para el control de este insecto, las prácticas de seguridad utilizadas y las personas que realizan la actividad de aplicación de los insecticidas, además del servicio de asesoría recibido y las intoxicaciones registradas entre los productores.

\section{Materiales y métodos}

El presente trabajo se llevó a cabo en el municipio de los Reyes de Juárez, Puebla (Figura 1); el cual se encuentra ubicado en la parte central del estado, sus coordenadas geográficas son los paralelos $18^{\circ} 57^{\prime}$ de latitud norte y $97^{\circ}$ $48^{\prime}$ de longitud oeste; asimismo, se ubica a una altitud de 2 100 msnm(INEGI, 2010). Sus colindancias son: al norte con Tepeaca al sur con Cuapiaxtla de Madero, al este con San Salvador Huixcolotla y Acatzingo, y al oeste con Tepeaca.

El municipio cuenta con una superficie de $30.55 \mathrm{~km}^{2}$ de los cuales la superficie urbana abarca $4.70 \mathrm{~km}^{2}$. Se localiza en el Valle de Tepeaca, planicie que se extiende al centro de la meseta poblana y que se caracteriza por su suelo eminentemente calizo y por sus yacimientos de mármol (INAFED, 2009).

La principal actividad económica del municipio es la agricultura. Se reportan un total de 4079 hectáreas sembradas en el municipio, de las cuales 2573 son de riego (INEGI, 2009). Anteriormente existían cultivos de granos como: el maíz, frijol y haba; sin embargo, éste sistema ha cambiado y actualmente se observan mayoritariamente hortalizas como cebolla, col, cilantro, lechuga y zanahoria (INAFED, 2009).

En el valle de Tepeaca, al cual pertenece este municipio de los Reyes de Juárez, el espacio agrícola es diversificado, con alrededor de 40 cultivos cíclicos y perennes, siendo las hortalizas los cultivos de mayor importancia económica (Lugo-Morín et al., 2010). Para realizar el presente estudio y previo al inicio del trabajo de campo, se contactó a las autoridades municipales, explicándoles el motivo y objetivos del proyecto y solicitando permiso para visitar a los

\section{Materials and methods}

This work was carried out in the town of Los Reyes de Juárez, Puebla (Figure 1), which is located in the central part of the State, its geographical coordinates are the parallels $18^{\circ} 57^{\prime}$ North latitude and $97^{\circ} 48^{\prime}$ West longitude, also located at an elevation of 2100 meters (INEGI, 2010). Localized: north of Tepiaca, south of Cuapiaxtla de Madero, east with San Salvador Huixcolotla and Acatzingo, and west with Tepeaca.

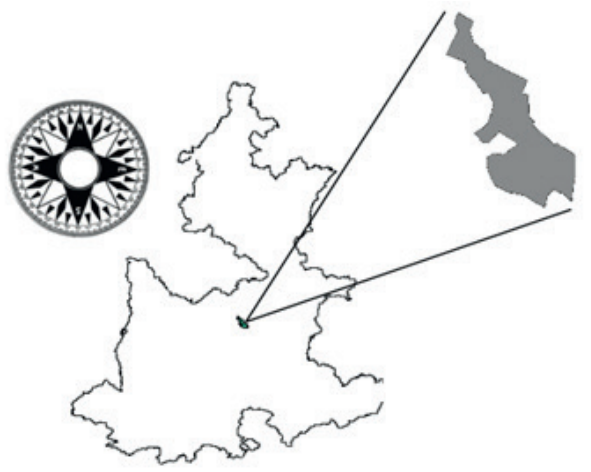

Figura 1. Ubicación geográfica del municipio de Los Reyes de Juárez, Puebla.

Figure 1. Geographic location of the municipality of Los Reyes de Juárez, Puebla.

The municipality has an area of $30.55 \mathrm{~km}^{2}$ of which the urban area covers $4.70 \mathrm{~km}^{2}$. It is located in the Valley of Tepeaca, plain extending to the center of the plateau of Puebla and its soil is characterized by predominantly limestone and its marble deposits (INAFED, 2009).

The main economic activity of the municipality is agriculture. Itreported a total of 4079 hectares in the municipality, of which 2573 have irrigation systems (INEGI, 2009). Previously, there weregrain crops such as maize, broadbeans and beans; however, this system has changed and is now seen mostly vegetables like onion, cabbage, cilantro, lettuce and carrot (INAFED, 2009).

In the Valleyof Tepeaca, which includes this municipality of Los Reyes de Juárez, the agricultural space is diversified, with around 40 cyclic and perennial crops, vegetable crops being most economically important (Lugo-Morin et al., 2010). In order to perform this study and prior to the start of the field work, we contacted the local authorities, explaining the purpose and objectives of the project and requesting permission to visit the producers selected in the sample, in order to implement the surveys and get the information necessary for the present study. Subsequently, a survey was designed as a tool for obtaining information. 
productores seleccionados en la muestra, con la finalidad de aplicar las encuestas y obtener la información necesaria para el presente estudio. Posteriormente se diseñó una encuesta como instrumento de obtención de la información.

El tamaño de muestra fue de 160 productores, determinado con el programa estadístico, con base en un marco de 1300 productores del municipio (Censo Agrícola, Ganadero y Forestal, 2007; INEGI, 2012), para la estimación de una proporción (distribución binomial) con varianza máxima ( $p=$ 0.5 y q $=0.5$ ), una tolerancia (error absoluto) de 0.08 y un nivel de confianzade $95 \%(\alpha=0.05)$. Los datos fueron analizadoscon estadística descriptiva, pormedio del programa: Statgraphics ${ }^{\circledR}$ (VersiónCenturionXVI).El instrumento(encuesta) seaplicóal azar entre los productores y se visitaron en sus zonas de trabajo (parcelas) o bien aprovechando las reuniones informativas organizadas por dependencias de gobierno.

El período de aplicación de encuestas fue de septiembre de 2011 a enero de 2012. Al momento de las entrevistas se registraron los datos generales de los entrevistados y se obtenía la información en relación al manejo de $S$. exigua y los daños provocados por dicho insecto en los cultivos. Las variables evaluadas fueron: 1) identificación del gusano soldado como plaga en los cultivos del municipio, para la obtención de esta información se llevaron larvas y adultos del insecto contenidas en recipientes plásticos con la finalidad de que fueran observadas e identificadas por los productores; 2 ) cultivos donde es más frecuente encontrar al gusano soldado; 3) nombre(s)comercial de él(olos) insecticidas utilizados para controlar a S. exigua; 4) personas encargadas de la aplicación delos insecticidas; 5) servicio (s) de asesoría recibidos para el manejo des. exigua; 6) elementos de protección utilizados para aplicar los insecticidas (cubrebocas, guantes, botas, etc.); y 7) intoxicación como resultado de emplear los insecticidas para el control de s. exigua. La información se registró en una base de datos delPrograma EXCELOffice (2007), para Windows ${ }^{\mathbb{R}}$ y posteriormente fueron ingresados al programa estadístico SPSS $^{\circledR}$ para su análisis estadístico.

\section{Resultados y discusión}

\section{Características generales de los productores entrevistados}

En total se entrevistaron a 117 hombres (73.1\%) y 43 mujeres (26.9\%). La edad media de los entrevistados fue de 40 años y la moda de 30 años. La escolaridad de los mismos en
The sample size was 160 producers, determined with the statistical program, based on a framework of 1300 producers in the municipality (Census of Agriculture, Livestock and Forestry, 2007, INEGI, 2012), to estimate a proportion (binomial distribution) with maximum variance ( $p=0.5$ and $\mathrm{q}=0.5$ ), a tolerance (absolute error) of 0.08 and a confidence level of $95 \%(\alpha=.05)$. Data were analyzed with descriptive statistics, through the program: Statgraphics ${ }^{\circledR}$ (Version Centurion XVI). The instrument (survey) was applied randomly between producers and were visited in their work areas (plots) or taking advantage of briefings organized by government agencies.

The survey implementation period was September, 2011 to January, 2012. At the time of the interviews were recorded general data of the respondents and the information was obtainedregarding themanagementofS. exigua and the damage to crops. The variables evaluated were: 1) identification of a pest of armyworm on the crops of the municipality, to obtain this information were carried insect larvae and adults contained in plastic containers for the purpose they were observed and identified by producers; 2 ) crops which are more frequently found to armyworm; 3) commercial names of the insecticides used to control S. exigua; 4) persons responsible for applying insecticides; 5) service received advise for handling S. exigua; 6) protection elementsused to apply insecticides (mask, gloves, boots, etc..); and 7) poisoning as a result of using insecticides to control $S$. exigua. The information was recorded in a database of EXCEL Program Office (2007), for Windows ${ }^{\circledR}$ and subsequently entered into SPSS ${ }^{\circledR}$ statistical software for statistical analysis.

\section{Results and discussion}

\section{General characteristics of the farmers interviewed}

In total, 117 men were interviewed (73.1\%) and 43 women $(26.9 \%)$. The average age of respondents was 40 years. Schooling for most of them was elementary basic level either complete or truncated. According to Ramírez (2009), small producers of the Valley of Tepeaca area, which belongs to the municipality of Los Reyes de Juárez, are aged between 30 and 65 years, with an average of 3.5 ha per farm. Also, Lugo-Morin et al. (2010) mentioned that among the elements of this sector include: the land, local knowledge, labor and financial resources allowing them some autonomy regarding what, when, how and how much to produce. 
su mayoría correspondió al nivel básico primaria ya sea completa o trunca. Según Ramírez (2009), los pequeños productores de la zona del Valle de Tepeaca, a la cual pertenece el municipio de Los Reyes de Juárez, tienen una edad entre 30 y 65 años, con un promedio de 3.5 ha por unidad productiva. Asimismo, Lugo-Morín et al. (2010), mencionan que entre los elementos que integran a este sector destacan: la propiedad de la tierra, el conocimiento local, la fuerza laboral y los recursos económicos que les permite cierta autonomía referente a qué, cuándo, cómo y cuánto producir.

\section{Incidencia y cultivos afectados por $S$. exigua}

Para el parámetro 1) identificación del gusano soldado como plaga/insecto nocivo en los cultivos del municipio; $93 \%$ de los entrevistados respondió afirmativamente cuando se les preguntó si reconocían a S. exigua como un insecto presente en el municipio (Figura 2A) y $85 \%$ identificaron a dicho insecto como plaga que afecta sus cultivos (Figura 2B).
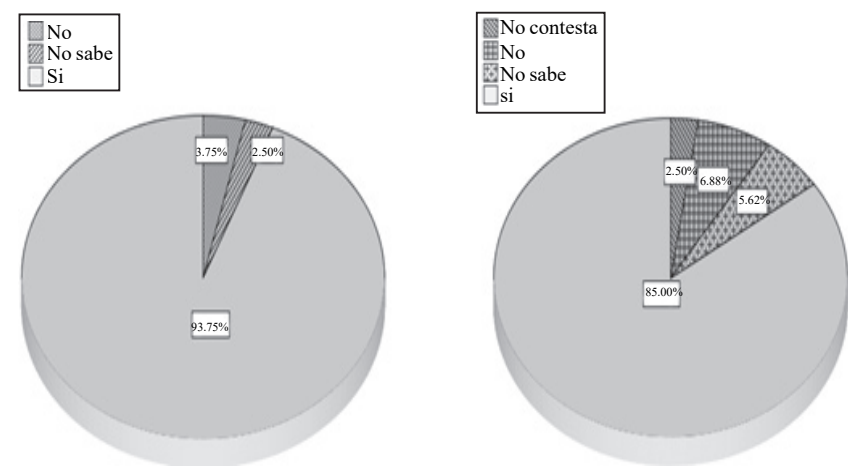

Figura 2A. Izquierda. Reconoce a S. exigua como plaga presente en el municipio de Los Reyes de Juárez, Puebla. Figura 2B. Derecha. S. exigua afecta los cultivos.

Figure 2A. Left. Recognize $S$. exigua as a pests present in the municipality of Los Reyes de Juárez, Puebla. Figure 2B. Right. S.exigua affecting the crops.

Para el caso de los cultivos donde es frecuente encontrar al gusano soldado se mencionaron los siguientes: acelga, alfalfa, apio, betabel, brócoli, cebolla, cilantro, col, coliflor espinaca, flor de alhelí, lechuga, rábano y zanahoria. De éstos el mayor número de menciones se refirieron al brócoli y col, cuya especie es Brassica oleracea (Brassicaceae) var. Italica y var. Capitata respectivamente. Sin embargo, también se encontrón casos para el cultivo de acelga (Beta vulgaris var. Cicla) (Amaranthaceae) y espinaca (Spinacia Oleraceae) (Amaranthaceae) (Cuadro 1).

\section{Incidence and crops affected by $S$. exigua}

For the parameter 1)identification of armywormas apest/insect on crops in the municipality, $93 \%$ of respondents answered positively when asked if they recognized $S$. exigua as a bug present in the municipality (Figure 2A) and 85\% identified this insect as a pest that affects their crops (Figure 2B).

The crops where it is common to find armyworm were mentioned the following: chard, alfalfa, celery, beets, broccoli, onion, cilantro, cabbage, cauliflower, spinach, flower wallflower, lettuce, radish and carrot. Of these the highest number of mentions referred to broccoli and cabbage, whose species is Brassica oleracea (Brassicaceae) var. Italica and var. Capitata respectively. However, there wer also cases for chard (Beta vulgaris var. Cicla) (Amaranthaceae) and spinach (Spinacia oleraceae) (Amaranthaceae) (Table 1).

Cuadro 1. Cultivos afectados por S. exigua según opinión de los productores del municipio de Los Reyes de Juárez, Puebla.

Table 1.Crops affected by $S$. exigua according to the producers in the municipality of Los Reyes de Juárez, Puebla.

\begin{tabular}{|c|c|c|}
\hline Cultivo & $\begin{array}{l}\text { Frecuencia- } \\
\text { menciones }\end{array}$ & $(\%)$ \\
\hline $\begin{array}{c}\text { Acelga Beta vulgaris var. Cicla } \\
\text { (Amaranthaceae) }\end{array}$ & 44 & 17.7 \\
\hline $\begin{array}{l}\text { Alfalfa Medicago sativa } \\
\text { (Leguminosae) }\end{array}$ & 2 & 0.8 \\
\hline Apio Apium graveolens (Apiaceae) & 6 & 2.4 \\
\hline $\begin{array}{l}\text { Brócoli Brassica oleraceae var. Italica } \\
\text { (Brassicaceae) }\end{array}$ & 44 & 17.7 \\
\hline $\begin{array}{c}\text { Betabel Beta vulgaris var. Conditiva } \\
\text { (Amaranthacea) }\end{array}$ & 15 & 6 \\
\hline Cebolla Alium cepa (Amaryllidaceae) & 2 & 0.8 \\
\hline $\begin{array}{c}\text { Coliflor Brassica oleraceae var. } \\
\text { Botrytis (Brassicaceae) }\end{array}$ & 15 & 6 \\
\hline $\begin{array}{c}\text { Cilantro Coriandrum sativum } \\
\text { (Apiaceae) }\end{array}$ & 7 & 2.8 \\
\hline $\begin{array}{c}\text { Col Brassica oleraceae var. Capitata } \\
\text { (Brassicaceae) }\end{array}$ & 43 & 17.3 \\
\hline $\begin{array}{c}\text { Espinaca Spinacia oleraceae } \\
\text { (Amaranthaceae) }\end{array}$ & 41 & 16.5 \\
\hline $\begin{array}{c}\text { Alhelí Cheiranthus cheiri } \\
\text { (Brassicaceae) }\end{array}$ & 4 & 1.6 \\
\hline Lechuga Lactuca sativa (Asteraceae) & 20 & 8.1 \\
\hline $\begin{array}{c}\text { Rábanos Raphanus sativus } \\
\text { (Brassicaceae) }\end{array}$ & 4 & 1.6 \\
\hline Zanahoria Daucus carota (Apiaceae) & 1 & 0.4 \\
\hline
\end{tabular}

Fuente: elaboración propia. $\mathrm{n}=160$ productores. 


\section{Insecticidas utilizados en el control de $S$. exigua en los cultivos afectados}

En cuanto a los nombres comerciales de los insecticidas utilizados para controlar a $S$. exigua, se mencionaron 17 productos, de los cuáles, los que se mencionaron con mayor frecuencia fueron: Foley-rey ${ }^{\circledR}$ (Clorpirifos-Permetrina) con 49 menciones y Furadán ${ }^{\circledR}$ (Carbofurán) con 47 . De acuerdo con el principio activo, los insecticidas más mencionados fueron Clorpirifos, Carbofurán y Cipermetrina.

De acuerdo con los grupos toxicológicos, los insecticidas más utilizados para el control del gusano soldado $S$. exigua pertenecen a los Oganofosforados-Piretroides, así como al grupo de los Carbamatos-Piretroides (Cuadro 2). Hubo escasas menciones de insecticidas biorracionales del grupo Naturalite, como Tracer/Spinosad y Proclaim/Benzoato de emamectina, obtenidos a partir de los microorganismos Saccharopolyspora spinosa y Streptomyces avermitilis, respectivamente. Éste nuevo tipo de insecticidas es poco conocido entrelos productores, principalmente tratándose de aquellos cuyo principio activo es a base de microorganismos entomopatógenos.

\section{Insecticides used in the control of S. exigua in the affected crops}

Regarding the tradenames of the insecticides used to control S. exigua, were mentioned 17 products, of which, those mentioned most frequently were: Foley-rey ${ }^{\circledR}$ (ChlorpyrifosPermethrin) with 49 mentions and Furadan ${ }^{\circledR}$ (Carbofuran) with 47. According to the active principle, the most mentioned insecticides were chlorpyrifos, carbofuran and cypermethrin.

According to the toxicological groups the insecticides mostly used for the control of beet armyworm $S$. exigua belong to Oganofosforados-pyrethroids, and the group of carbamates, pyrethroids (Table 2). There was little mention of biorational insecticides of the Naturalite group such as Tracer/Spinosad and Proclaim/ emamectin benzoate, obtained from Saccharopolyspora spinosa microorganisms and Streptomyces avermitilis, respectively. This new type of insecticide is little known among the producers, especially in the case of those whose active ingredient is based on entomopathogenic microorganisms.

Cuadro 2. Insecticidas utilizados en los cultivos afectados por $S$. exigua.

Table 2. Insecticides used on crops affected by $S$. exigua.

\begin{tabular}{cccccc}
\hline $\begin{array}{c}\text { Nombre } \\
\text { comercial }\end{array}$ & Principio activo & Grupo toxicológico & $\begin{array}{c}\text { Clase } \\
\text { Toxicológica }\end{array}$ & $\begin{array}{c}\text { Frecuencia/ } \\
\text { Menciones }\end{array}$ & Porcentaje \\
\hline Ammate $^{\circledR}$ & Indoxacarb & Oxadiazina & III & 9 & 4.2 \\
Ambush $^{\circledR}$ & Permetrina & Piretroide & III & 3 & 1.4 \\
Arrivo $^{\circledR}$ & Cipermetrina & Piretroide & III & 26 & 12.0 \\
Cipermetrina $^{\circledR}$ & Cipermetrina & Piretroide & III & 3 & 1.4 \\
Combat $^{\circledR}$ & Cipermetrina & Piretroide & III & 11 & 5.1 \\
Coragen $^{\circledR}$ & Rynaxypyr & Diamidas-antranílicas & IV & 1 & 0.5 \\
Disparo $^{\circledR}$ & Clorpirifos etily Permetrina & Organofosforado-Piretroide & III & 34 & 15.7 \\
Flash ultra $^{\circledR}$ & Clorpirifos etil & Organofosforado & III & 3 & 1.4 \\
Foley-rey $^{\circledR}$ & Clorpirifos y Permetrina & Organofosforado-Piretroide & III & 49 & 22.7 \\
Furadán $^{\circledR}$ & Carbofurán & Carbamato & II & 47 & 21.8 \\
Lucasulfan $^{\circledR}$ & Endosulfán & Organoclorado & II & 1 & 0.5 \\
Muralla $^{\circledR}$ & Imidacloprid y Cyclutrin & Cloronicotínico-Piretroide & III & 4 & 1.9 \\
Proclaim $^{\circledR}$ & Benzoato de emamectina & Avermectina (Natural) & II & 3 & 1.4 \\
Rogor $^{\circledR}$ & Dimetoato & Organofosforado & III & 1 & 0.5 \\
Tamarón $^{\circledR}$ & Metamidofos & Organofosforado & I & 9 & 4.2 \\
Thiomet $^{\circledR}$ & Endosulfán & Organoclorado & II & 1 & 0.5 \\
Tracer $^{\circledR}$ & Spinosad & Lactona macrocíclica (Natural) & III & 11 & 5.1
\end{tabular}

Fuente: elaboración propia. $\mathrm{n}=160$ productores. 
En el caso del presente trabajo existieron algunas menciones para el uso de estos últimos; sin embargo, como ya se indicó, losquetuvieronmayormención fueron aquellos pertenecientes a los Organofosforados-Piretroides; es decir, una mezcla de productos insecticidas pertenecientes a estos grupos. El conocimiento sobre el manejo químico contra plagas en una región agrícola es muy importante, ya que los insecticidas aplicados regularmentepueden habersido superados porlagran capacidad de adaptación de los insectos, como es el caso de $S$. exigua yúnicamente presentarefectos adversos aotras especies y al ambiente, sin controlar el problema del insecto plaga.

Cabe recordar la resistencia reportada de $S$. exigua en diversos grados, que van desde leve a moderado, frente grupos toxicológicos de insecticidas, como son los organoclorados, organofosforados, carbamatos y piretroides (Gore y Adamczyk, 2004; Ahmad y Arif, 2010), así como al Spinosad (Wang et al., 2006). En cuanto a la clasificación toxicológica, la mayor parte de los insecticidas que se utilizan en la región, pertenecen al grupo III, considerados de moderada a ligeramente tóxicos; sin embargo, muchos de ellos cuentan con antecedentes de afecciones al ambiente. Asimismo, se observó el uso de insecticidas del grupo II (Carbofurán), considerado altamente tóxico.

Es importante comentar que Puebla se encuentra entre los estados con mayor uso de plaguicidas, junto con Sinaloa, Veracruz, Jalisco, Nayarit, Colima, Sonora, Baja California, Tamaulipas, Michoacán, Tabasco, Estado de México y Oaxaca, con aproximadamente $80 \%$ de los plaguicidas que se usan en México (Albert, 2005). Huerta-de la Peña et al. (2010), mencionan que en el estado de Puebla no está documentada con precisión la información referente a la cantidad de plaguicidas utilizados en los diversos cultivos; sin embargo, de acuerdo a la experiencia de técnicos y productores de la región, se sabe que el control químico es el método comúnmente utilizado y que se aplica en gran cantidad en cultivos de hortalizas y ornamentales, en las regiones de San Martín Texmelucan, Tecamachalco, Atlixco y Tehuacán. Generalmente las aplicaciones de insecticida son continuas para un mismo cultivo.

\section{Personas que realizan la aplicación de los insecticidas aplicados en el control convencional de $S$. exigua.}

En relación a quien realiza la aplicación de los insecticidas, la mayor parte de los productores (59.4\%) indicaron ser ellos mismos; sin embargo, $23.8 \%$ comentó contratar peones que los ayudan (Cuadro 3), lo que coincide con estudios previos
In the case of this study there were some references to the use of the latter; however, as already indicated, those who were more refereed belong to the Organophosphates, pyrethroids, i.e. a mixture of insecticides belonging to these groups. Knowledge about chemical management of pests in an agricultural region is very important as regularly applied insecticides may have been overcome by the high adaptability of insects, such as S. exigua and have only adverse effects to other species and the environment, without controlling the insect pest.

It should be noted that, the reported resistance of $S$. exigua in different degrees, ranging from mild to moderate, compared to toxicological groups of insecticides, such as organochlorines, organophosphates, carbamates and pyrethroids (Gore and Adamczyk, 2004; Ahmad and Arif, 2010), as well as Spinosad (Wang et al ., 2006). Regarding the toxicological classification, most of the insecticides used in the region, belong to group III, considered moderately to slightly toxic, but many of them have a history of disease to the environment. It was also noted the use of insecticides in group II (Carbofuran), considered highly toxic.

It is important to note that Puebla is among the States with the highest use of pesticides, along with Sinaloa, Veracruz, Jalisco, Nayarit, Colima, Sonora, Baja California, Tamaulipas, Michoacán, Tabasco, Mexico and Oaxaca State, with approximately $80 \%$ of pesticides used in Mexico (Albert, 2005). Huerta-de la Peña et al. (2010) mentioned that in the State of Puebla is not accurately documented information concerning the amount of pesticides used on various crops, but according to the experience of technicians and producers of the region, it is known that chemical control is the method commonly used and applied in large quantities in vegetable and ornamental crops in the regions of San Martin Texmelucan, Tecamachalco, Atlixco and Tehuacan. Generally, the application of insecticides are continuous for the same crop.

\section{People performing the application of insecticides applied in conventional control $S$. exigua.}

In relation to the person making the application of insecticides, most of the producers $(59.4 \%)$ reported doing it themselves, but $23.8 \%$ said that recruit laborers (Table 3 ), which is consistent with previous studies such as LugoMorin et al. (2010), who found that the horticultural activity in the Valley of Tepeaca ares rests in the family, and the hiring of labor, as seen in the specific case of pest control . 
como el de Lugo-Morín et al. (2010), quienes encontraron que la actividad hortícola de la zona del Valle de Tepeaca descansa en la familia, así como la contratación de fuerza de trabajo, tal como se observa en el caso específicos del control de plagas.

\section{Asesoría, equipo de protección e intoxicaciones al aplicar los insecticidas}

Con respecto a esta variable, los productores reciben muy poca o nula asesoría profesional técnica para el manejo de los insecticidas utilizados en el control de plagas, tal como sucede en otras regiones del país, por ejemplo, en el estado de Chiapas se investigó el criterio usado por los productores para elegir los insecticidas para el manejo de plagas en cultivos de tomate y se encontró que $98 \%$ de los agricultores considera la recomendación de susvecinos y rara vez recurren al técnico de la SAGARPA; asimismo, la aspersión la realizan tomando en consideración lo recomendado por el vendedor del insecticida Ruiz-Nájera et al. (2011).

Este resultado es preocupante en el municipio de los Reyes de Juárez, ya que la carencia de asesoría o la falta de ella tiene consecuencias adversas tanto al ambiente como a la salud de los productores, debido al empleo de altas dosis en la cantidad del insecticida aplicado, las aplicaciones numerosas y la combinación de varios insecticidas ó mezclas en períodos sucesivos y cortos de tiempo, lo que es una constante en la región de estudio, ya que además se observó que suelen realizarse mezclas de todos los agroquímicos (insecticidas, fertilizantes y fungicidas). En relación con las medidas de protección para la aplicación de insecticidas en esta región; $45 \%$ de los productores mencionó que no utiliza protección alguna para fumigar, sólo $15 \%$ de los agricultoresutiliza alguna protección, siendo lo más frecuente las botas o cubre bocas y únicamente una persona comentó que utiliza impermeable junto con otros elementos de protección (Cuadro 4).

Todos los insecticidas mencionados tienen indicaciones de manejo que incluyen los elementos de seguridad o protección necesarios para realizar la aplicación de los mismos; sin embargo, es frecuente que los agricultores no se protejan adecuadamente con ropa especial, goles, botas, mascarilla o ropa especial. Por el contrario, es común observar personas fumigando sin calzado; varios de ellos comentaron que es incómodo realizar las actividades de fumigación con impermeable, guantes y lentes, además de que desconocen la gravedad de los riesgos por intoxicación de los insecticidas y no distinguen claramente entre los diferentes grados de toxicidad de los mismos.
Advice, protective equipment and poisoning when applying insecticides

With respect to this variable, the producers receive little or no technical advice for handling insecticides used to control pests, such as in other regions, for example, in the State of Chiapas investigated the criterion used by producers to choose insecticides for pest management in tomato and found that $98 \%$ of farmers considered the recommendation of their neighbors and rarely resort to technical from SAGARPA; also, spraying is carried out taking into consideration the recommendations of the seller of the insecticide Ruiz-Najera et al. (2011).

Cuadro 3. Personas que realizan la aplicación de los insecticidas en los cultivos afectados por $S$. exigua en el municipio de Los reyes de Juárez, Puebla.

Table 3. Persons performing the application of insecticides in crops affected by $S$. exigua in the municipality of Los Reyes de Juárez, Puebla.

\begin{tabular}{ccc}
\hline $\begin{array}{c}\text { Realiza la aplicación del (los) } \\
\text { insecticida (s) }\end{array}$ & Frecuencia & (\%) \\
\hline El productor únicamente & 95 & 59.4 \\
El productor y familia cercana & 2 & 1.3 \\
$\quad$ (hijos, esposa) & & \\
El productor y familiares & 6 & 3.8 \\
El productor y personas & 5 & 3.1 \\
$\quad$ contratadas & 7 & 4.4 \\
$\quad \begin{array}{c}\text { Otros familiares } \\
\text { Personas contratadas } \\
\text { únicamente }\end{array}$ & 38 & 23.8 \\
No respondió & 7 & 4.4 \\
\hline
\end{tabular}

Fuente: elaboración propia. $\mathrm{n}=160$ productores.

This result is troubling in the municipality of Los Reyes de Juárez, since the lack of advice has adverse consequences for both the environment and the health of farmers, due to the use of high doses in the amount of insecticide applied , numerous applications and a combination of insecticides or mixtures and short successive periods of time, which is a constant in the region of study, since it was observed that all blends are usually carried in agrochemicals (pesticides, fertilizers, and fungicides). In relation to the protection measurements for the application of insecticides in this region, $45 \%$ of farmers mentioned that they do not use any protection at all, only $15 \%$ of farmers use some protection, and is most often the boots or surgical masks and only one person commented that uses waterproof along with other protective elements (Table 4). 
Cuadro 4. Elementos de protección utilizados por los agricultores del municipio de los Reyes de Juárez, al aplicar insecticidas en el control de S. exigua.

Table 4. Protection elements used by farmers in the municipality of Los Reyes de Juárez, applying insecticides in the control of $S$. exigua.

\begin{tabular}{|c|c|c|}
\hline Elemento & $\begin{array}{l}\text { Frecuencia } \\
\text { (menciones) }\end{array}$ & $(\%)$ \\
\hline Guantes solamente & 5 & 3.1 \\
\hline Guantes y cubrebocas & 11 & 6.9 \\
\hline Guantes, cubrebocas y botas & 6 & 3.8 \\
\hline Guantes, cubrebocas e impermeable & 1 & 0.6 \\
\hline Cubrebocas únicamente & 14 & 8.8 \\
\hline Guantes,cubrebocas y lentes & 4 & 2.5 \\
\hline Guantes, cubrebocas, lentes y botas & 1 & 0.6 \\
\hline Ninguno & 72 & 45 \\
\hline Pañuelo & 3 & 1.9 \\
\hline Botas & 24 & 15 \\
\hline Botas y guantes & 1 & 0.6 \\
\hline Botas y cubre bocas & 9 & 5.6 \\
\hline Botas y pañuelo & 1 & 0.6 \\
\hline No respondió & 8 & 5 \\
\hline
\end{tabular}

Fuente: elaboración propia. $\mathrm{n}=160$ productores.

En éste sentido, Badii-Mohammad y Varela (2008), comentan que un problema asociado al uso de insecticidas agrícolas, es el hecho de que los aplicadores no poseen equipo de protección y sugieren una mayor información a los agricultores sobre los riesgos que acarrea el manejo de sustancias tóxicas. Ruíz-Nájera et al. (2011), en un estudio similar mencionan que $90 \%$ de los productores no utilizan el equipo completo de protección personal el cual incluye: mascarilla, anteojos, guantes y botas, esto asociado a la incomodidad de utilizar el equipo y también por ignorar los daños que causan los plaguicidas a la salud humana.

En el caso de intoxicaciones debidas al uso de los plaguicidas en los cultivos afectados por S. exigua, se encontró que el número de intoxicaciones ha alcanzado un porcentaje de hasta $18.8 \%$, mientras que $67 \%$ comentó no haberse intoxicado con los insecticidas (Cuadro 5). Martínez-Valenzuela y Gómez-Arroyo (2007), mencionan que $80 \%$ de los casos de intoxicación por plaguicidas ocurre en países en vías de desarrollo y que para el caso de México se emplean aproximadamente 260 marcas de las cuales 24 están prohibidas y 13 restringidas, siendo las principales causas de intoxicación las deficientes medidas de control y previsión.
All insecticides mentioned have driving directions that include the security and protection necessary for the application, but the farmers often do not adequately protect clothing, boots, masks or special clothing. On the contrary, it is common to see people spraying without shoes, and several of them said they are uncomfortable performing fumigation activities impervious gloves and goggles, plus they know the severity of poisoning risks of insecticides and do not clearly distinguish between different degrees of toxicity.

In this sense, Badii-Mohammad and Varela (2008) commented that one problem associated with the use of agricultural insecticides is that applicators do not have protective equipment and suggest greater information to farmers about the risks involved in management of toxic substances. Ruiz-Najera et al. (2011), in a similar study mentioned that $90 \%$ of farmers do not use full personal protective equipment which includes: mask, goggles, gloves and boots, this discomfort is associated when using the equipment and ignore the damage that the pesticides cause to human health.

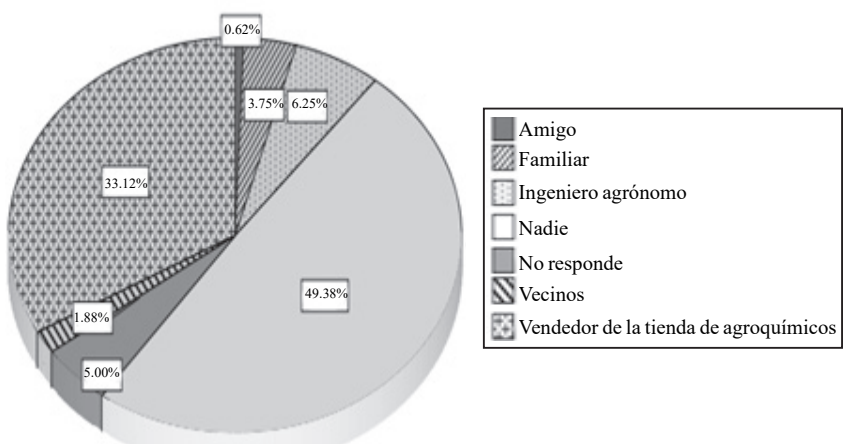

Figura 3. Servicio de asesoría recibido por los productores para el uso de insecticidas utilizados en el manejo del gusano soldado en el municipio de Los Reyes de Juárez, Puebla.

Figure 3. Counseling service received by producers for the use of insecticides used in the management of armyworm in the municipality of Los Reyes de Juárez, Puebla.

In the case of poisoning due to the use of pesticides on crops affected by S. exigua, it was found that the number of poisoning has reached a rate of up to $18.8 \%$, while $67 \%$ said not been poisoned with insecticides (Table 5). MartínezGómez and Arroyo-Valenzuela (2007) mentioned that 80\% of cases of pesticide poisoning occur in developing countries and in the case of Mexico are employed approximately 260 brands of which 24 are prohibited and 13 restricted, the main causes of poisoning of poor control measures and forecasting. 
Los efectos por exposición a plaguicidas pueden ser agudos; es decir, manifestarse tempranamente con vómitos, cefaleas y convulsiones, síntomas que mencionaron algunos de los productores entrevistados. También se han asociado a problemas de cáncer o bien los síntomas aparecen después de un largo periodo de exposición, lo cual dificulta su detección, ya que su biotransformación es lenta y provoca efectos acumulados en las personas que se expusieron a dichas sustancias (Potti et al., 2003).

Ruiz-Nájera et al. (2011), señalan la importancia de la capacitación técnica de los productores y de los técnicos agrícolas para que estos adopten prácticas agrícolas con un menor impacto negativo en la salud humana y del ambiente, así como del establecimiento de una coordinación de las actividades agrícolas, que involucre gobierno y sector social. Dichos comentarios aplican indiscutiblemente para el presente trabajo, ya que es urgente un manejo diferente de los plaguicidas que implique mayor conciencia y responsabilidad de todos los actores que participan de un modo u otro en el proceso de producción.

\section{Conclusiones}

Los cultivos más comúnmente afectados por $S$. exigua en el municipio de los Reyes de Juárez, Puebla son: Brassica oleraceae var. Italica (brócoli), Beta vulgaris var. Cicla (acelga), Brassica oleraceae var. Capitata (col) y Spinaceae oleraceae (espinaca).

Los insecticidas más empleados en el control del gusano soldado son aquellos que contienen como principio activo Clorpirifos y Permetrina (Organofosforado-Piretroide) así como Carbofurán (Carbamato).

La asesoría técnica-profesional y protección para el manejo de insecticidas utilizados en el control de S. exigua es mínima o nula.

La aplicación de insecticidas es realizada por el propio productor en $59 \%$ o bien por personas contratadas para dicha actividad en $23.8 \%$.

El $18.7 \%$ de los productores en el municipio, ha sufrido alguna intoxicación como consecuencia de su exposición a los insecticidasutilizados en el manejodel gusano soldado S. exigua.
The effects of exposure to pesticides may be acute, i.e. manifest quite fast with vomiting, headache and convulsions, symptoms mentioned by some of the farmers interviewed. Also been associated with cancer problems or symptoms appear after a long period of exposure, making it difficult to detect because its biotransformation is slow and causes cumulative effects in people exposed to these substances (Potti et al., 2003).

Ruiz-Nájera et al. (2011), point out the importance of technical training for the farmers and agricultural technicians so that they adopt agricultural practices less negative for the human health and the environment, as well as the establishment of a coordination of agricultural activities, involving government and social sector. These comments apply to this work unquestionably as urgent a differentmanagement of pesticides involving awareness and responsibility of all actors involved in one way or another in the production process.

Cuadro 5. Casos de intoxicaciones de productores como resultado del de insecticidas utilizados en el control de $S$. exigua.

Table 5. Producers poisoning cases resulting from insecticide used in the control of S. exigua.

\begin{tabular}{ccc}
\hline Se ha intoxicado & Frecuencia & $\mathbf{( \% )}$ \\
\hline Sí & 30 & 18.8 \\
No & 108 & 67.5 \\
No sabe & 16 & 10.0 \\
No responde & 6 & 3.8 \\
\hline
\end{tabular}

Fuente: elaboración propia. $\mathrm{n}=160$ productores.

\section{Conclusions}

The crops most commonly affected by $S$. exigua in the Los Reyes de Juárez, Puebla are Brassica oleraceae var. Italica (broccoli), Beta vulgaris var. Cicla (beet), Brassica oleraceae var. Capitata (cabbage) and Spinaceae oleraceae (spinach).

The most commonly used insecticides in the control of armyworm are those containing as active ingredient in Chlorpyrifos and Permethrin (Organophosphate, Pyrethroid) and carbofuran (carbamate). 
Es urgente considerar el diseño y aplicación de una estrategia efectiva de capacitación y transferencia de tecnología de manejo adecuado de insecticidas y de alternativas sustentables para el manejo integrado del gusano soldado en esta región, con el propósito de disminuir riesgos por contaminación e intoxicaciones de productores por el uso inadecuado de insecticidas de síntesis.

\section{Agradecimientos}

A las autoridades del municipio de Los Reyes de Juárez, Puebla, por la apertura y permisos otorgados para la obtención de la información presentada en este trabajo. Particularmente a los productores del municipio mencionado, porsu paciencia y tiempo durante las entrevistas realizadas. Al Consejo Nacional de Ciencia y Tecnología (CONACYT) por otorgar una beca de estudios de maestría a la estudiante: J. Estefany Barrientos, primera autora del presente trabajo. AlColegio de Postgraduados, Campus Puebla y a la LPI 10 Desarrollo Rural Sustentable, por su apoyo en el financiamiento del presente trabajo de investigación.

\section{Literatura citada}

Ahmad, M. and Arif, M. I. 2010. Resistance of beet armyworm Spodoptera exigua (Lepidoptera: Noctuidae) to endosulfan, organophosphorus and pyrethroid insecticides in Pakistan. Crop Protec. 29:1428-1433.

Albert, A. L. 2005. Panorama de los plaguicidas en México. In: VII Congreso de actualización en toxicología clínica. Nayarit. Septiembre $5 \mathrm{p}$.

Aragón, A. y López-Olguín, J. F 2001. Descripción y control de las plagas del amaranto de la Benemérita Universidad Autónoma de Puebla (BUAP). Publicación especial. México. 7 y 8 pp.

Badii-Mohammad, H. y Varela, S. 2008. Insecticidas organofosforados: efectos sobre la salud y el ambiente. Cultura científica y tecnológica- toxicología de insecticidas. 5(28):15.

Capinera, J. L. 2005. Beet armyworm, Spodoptera exigua (Hübner) (Insecta: Lepidoptera: Noctuidae). Institute of food and Agricultural Sciences, University Of. Florida. 1-3 pp.

Gore, J. and Adamczyk, J.J. 2004. Laboratory seleccion for beet armyworm (Lepidoptera: Noctuidae) resistance to methoxyfenozide. Florida Entomol. 87(4):450-453.

Greenberg, S. M.; Showler, A. T. and Liu, T. X. 2005. Effects of neem-based insecticides on beet armyworm (Lepidoptera: Noctuidae). Insect Sci. 12:17-23.
The technical and professional advice for the management and protection of insecticides used in the control of S. exigua is minimal or nonexistent.

The insecticide application is made by the producer at $59 \%$ or by persons employed for such activity in $23.8 \%$.

The $18.7 \%$ of farmers in the village has experienced some intoxication as a result of their exposure to the insecticides used in the management of S. exigua.

It is urgent to consider the design and implementation of an effective strategy for training and for technology transfer as a proper management and sustainable alternative for insecticides integrated in this region, with the aim of reducing pollution and poisoning risks of producers improper use of synthetic insecticides.

End of the English version

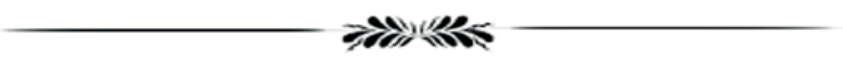

Huerta-de la Peña, A.; Viñuela, S. E. and Medina, V. M. P. 2010. Tendencias actuales para el manejo de insectos plaga en la agricultura. In: cultivos sanos (manejo de plagas y enfermedades con bajo impacto ambiental). Huerta- de la Peña, A. y Díaz-Ruíz, R. (Eds.). Colegio de Postgraduados en Ciencias. Altres costa-AMIC. 11-12 p.

Instituto Nacional de Estadística y Geografía (INEGI). 2009. México en cifras-información nacional por entidad federativa y municipio: datos del año 2009. http://www3.inegi.org.mx/ sistemas/mexicocifras/. (consultado marzo, 2011).

Instituto Nacional de Estadística y Geografía (INEGI). 2007. Datos del censo agrícola ganadero y forestal. http://www.inegi.org.mx/ sistemas/TabuladosBasicos/Default.aspx? $\mathrm{c}=17177 \& \mathrm{~s}=$ est (consultado marzo, 2011)

Lugo-Morín, D. R.; Ramírez-Juárez, J.; Méndez-Espinoza, J. A. y Peña-Olvera, B. B. 2010. Redes sociales asimétricas en el sistema hortícola del valle de Tepeaca, México. El Colegio Mexiquense, A. C. Rev. Economía, Sociedad y Territorio. 10(32):213

Martínez-Valenzuela, C. y Gómez-Arroyo, S. 2007. Riesgo genotóxico por exposición a plaguicidas en trabajadores agrícolas. Rev. Int. Cont. Amb. 23(4):187-188.

Palacios, N. M. E. 2003. Aplicación de un instrumento para evaluar exposición a plaguicidas organofosforados, efectos agudos y subagudos en la salud de trabajadores agrícolas. Rev. Fac. Med. Universidad Nacional Autónoma de México (UNAM). 46:22.

Pérez, P. F.; Montes de Oca, M.; Estévez, J. R. y Carnero. A. 2003. Una plaga potencial en los cultivos hortícolas de Canarias: Spodoptera exigua (Lepidoptera, Noctuidae). Rev. Granja 10:8-20. 
Potti, A.; Panwalkar, A. and Langness, P. 2003. Prevalence of pesticides exposure in Young males with adenocarcinoma of the prostate. J . Carcinongenesis. 2:4-5.

Ramírez, J. 2009. Recomposición agrícola del campesinado en el Valle de Tepeaca. In: Ferro, G y Lozano, F. (Eds.). La configuración de los territorios rurales en el siglo XXI. Pontifica Universidad Javeriana, Bogotá, Colombia. 263 pp.

Ruíz-Nájera, R. E.; Ruíz-Nájera J. A.; Guzmán-González, S. y PérezLuna, E. 2011. Manejo y Control de plagas del cultivo del tomate en Cintalapa, Chiapas, México. Universidad Nacional Autónoma de México (UNAM). Rev. Int. Cont. Amb. 27(2):129-137.
Secretaría de Agricultura, Ganadería, Pesca y Alimentación (SAGARPA). 2002. Norma oficial mexicana NOM-081-FITO-2001. Manejo y eliminación de focos de infestación de plagas, mediante el establecimiento o reordenamiento de fechas de siembra, cosecha y destrucción de residuos. In: Diario Oficial de la Federación (DOF). 47-50 pp.

Statistical Package for Social Sciences (SPSS). 2006. Versión 15.0.1. Chicago, Ilinois.

Wang, W.; Jianchu, M.; Cheng, J.; Zhuang, P. and Zhenhua, T. 2006. Selection and characterization of Spinosad resistance in Spodoptera exigua (Hübner) (Lepidoptera: Noctuidae). Pest. Bioch. Physiol. 84:180-187. 